\title{
Susceptibility of bacterioplankton to nutrient enrichment of oligotrophic and ultraoligotrophic lake waters
}

\author{
Roberto BERTONI*, Cristiana CALLIERI, Esteban BALSEIRO ${ }^{1)}$ and Beatriz MODENUTTI ${ }^{1)}$ \\ CNR - Institute of Ecosystem Study, Largo Tonolli 50, 28922 Verbania-Pallanza, Italy \\ ${ }^{1)}$ CONICET - UNC Laboratory of Limnology, Universidad Nacional del Comahue, Quintral 1250, 8400 Bariloche, Argentina \\ *email corresponding author: r.bertoni@ise.cnr.it
}

\begin{abstract}
We carried out laboratory experiments in one ultraoligotrophic pristine Andean lake (Lake Gutiérrez, Argentina) and in one subalpine lake that is now at the edge of the oligo- to mesotrophic condition (Lake Maggiore, Italy). Lake water was amended with phosphorus $(+P)$, organic carbon $(+C)$, alone or in combination $(+C P)$, to test for short-term changes $(48$ hours) in bacteria activity and community structure (CARD FISH). Experiments were carried out in spring and summer. Results showed that bacterial production increased in the $+C P$ treatment in both lakes, and in the $+P$ treatment in the ultroligotrophic lake. In both lakes the bacterial activity increased more rapidly in summer (within 24 hours). Bacteria composition changed in both seasons in all the treatments. At the beginning of the experiments the subclass of $\beta$-Proteobacteria dominated both lakes, while $\gamma$-Proteobacteria showed higher percentage in spring in Lake Maggiore and in summer in Lake Gutiérrez. After incubation, in spring and in particular in the $+C P$ treatment, we observed an increase in the relative importance of $\gamma$-Proteobacteria in both lakes, whereas in Lake Maggiore this group declined in the summer experiments following an increase in $\beta$-Proteobacteria. All our results indicate the different response of bacterioplankton in systems at the edges of the oligotrophic range.
\end{abstract}

Key words: bacterioplankton, ultraoligotrophic lake, oligotrophic lake, phosphorus addition, carbon addition

\section{INTRODUCTION}

In oligotrophic lakes, bacterioplankton always exhibits low metabolic activity and is commonly limited by inorganic nutrients and organic carbon, alone or in combination (Chrzanowski et al. 1995; Vrede 1996). On one hand, the availability of dissolved organic carbon (DOC) is a key factor limiting bacterial growth and activity in lakes characterized by low DOC:nutrient ratios (Jansson et al. 2006). On the other hand there is evidence that the shortage of phosphorous supply could limit the bacterial production in oligotrophic lakes (Vadstein 2000; Biddanda et al. 2001; Jansson et al. 2006), notwithstanding that heterotrophic bacteria have been found to outcompete phytoplankton for phosphorus (Cotner \& Biddanta 2002). As expected, water temperature has a strong effect on the regulation of planktonic bacterial growth rates (Felip et al. 1996; Vrede 2005). Particularly in eutrophic environments bacterial growth appears to be temperature limited during winter and resource limited during summer (Felip et al. 1996).

Considering the importance of impact of human activities on oligotrophic water bodies, it is important to evaluate how responsive bacterial assemblages are to any minor increases in organic carbon and nutrient concentration. The Andean Patagonian lakes lie in the extreme edge of the oligotrophic gradient and represent interesting environments to study the response of bacterial communities to nutrient and substrate enrichment. On the other hand the subalpine Italian lakes, in par- ticular Lake Maggiore, stand at the borderline between the oligotrophic and mesotrophic conditions. The comparison of bacterioplankton community reaction of these two systems can help us understand the different degree of responses at the oligotrophic end of the trophic gradient. Therefore our main hypothesis is that the two systems would react differently to the enrichment manipulations.

The artificial resource enrichment was often used to find out the relative importance of carbon (C), nitrogen $(\mathrm{N})$ and phosphorus $(\mathrm{P})$ in stimulating bacterial production in oligotrophic (Coveney \& Wetzel 1992; Graneli et al. 2004), mesotrophic and eutrophic lakes (Schweitzer \& Simon 1995; Toolan et al. 1991). Phosphorus, rather than organic carbon, can limit bacterioplankton growth in P-deficient systems (Coveney \& Wetzel 1992). Nevertheless, there is evidence that both quantity (Eiler et al. 2003) and quality (Van Hannen et al. 1999) of available organic substrates can promote significant changes in bacterial community composition within a time span of a week to a month. Even in short-term experiments (up to 72 hours) the response of bacterioplankton to growth enhancing conditions seems to be driven by the growth capabilities of different bacterial phylogenetic lineages (Šimek et al. 2006). Nevertheless much of the experiments have been performed in mesoeutrophic systems and to our knowledge, no information exist on changes in taxonomic composition of bacterial assemblages induced by nutrient and substrate addition in ultraoligotrophic and oligotrophic waters. 
Tab.1. Location and features of the two lakes where the experiments were performed. $Z_{\max }=$ maximum depth, $K_{d P A R}=$ diffuse attenuation coefficient for the photosynthetic active radiation (PAR), $Z_{\text {therm }}=$ depth of thermocline, $T P=$ total phosphorus at winter overturn, $\mathrm{DOC}=$ dissolved organic carbon, seasonal mean.

\begin{tabular}{lccccccc}
\hline Lake & Location & $\begin{array}{c}\text { Area } \\
\left(\mathrm{km}^{2}\right)\end{array}$ & $\begin{array}{c}\mathrm{Z}_{\max } \\
(\mathrm{m})\end{array}$ & $\begin{array}{c}\mathrm{K}_{\mathrm{dPAR}} \\
\left(\mathrm{m}^{-1}\right)\end{array}$ & $\begin{array}{c}Z_{\text {therm }} \\
(\mathrm{m})\end{array}$ & $\begin{array}{c}\text { TP mean } \pm \text { s.e. } \\
\left.(\mu \mathrm{g} \mathrm{L})^{-1}\right)\end{array}$ & $\begin{array}{c}\text { DOC mean } \pm \text { s.e. } \\
\left(\mu \mathrm{g} \mathrm{L}^{-1}\right)\end{array}$ \\
\hline L.Maggiore & $45^{\circ} 55^{\prime} \mathrm{N}^{\circ} 32 \mathrm{E}$ & 212.2 & 372 & 0.22 & $\sim 15$ & $10 \pm 1$ & $1200 \pm 15$ \\
L.Gutiérrez & $41^{\circ} 15^{\prime} \mathrm{S} 71^{\circ} 33^{\prime} \mathrm{W}$ & 16.4 & 111 & 0.127 & 22.0 & $3.5 \pm 0.3$ & $657 \pm 9$ \\
\hline
\end{tabular}

The aim of the present study was to evaluate if enrichments with limiting nutrient (phosphorus), labile DOC or both affect bacterial activity in natural assemblages. The experiments were carried out in two periods of the year (spring and summer) when temperature and nutrient conditions were different. We tried to evaluate if a significant shift in bacterioplankton community structure becomes evident in short-term incubations (48 hours) with and without pulse of nutrients to natural lake water samples.

\section{MATERIAL AND METHODS}

\subsection{Study sites and sampling}

The experiments were performed with water from Lake Gutiérrez (Patagonia, Argentina) and Lake Maggiore (Northern Italy) (Tab. 1), in spring and summer.

Lake Gutiérrez is in pristine conditions and is located within the Nahuel Huapi National Park (Balseiro et al. 2007; Callieri et al. 2007). Lake Maggiore has recovered from the eutrophic state, reached at the end of the 1970s, and is now at the edge of the oligo- to mesotrophic conditions (Bertoni et al. 2004; Salmaso et al. 2007).

In both lakes sampling was performed in a pelagic station at the point of maximum depth. Discrete samples were taken with a $5 \mathrm{~L}$ Van Dorn type bottle at $10 \mathrm{~m}$ in Lake Maggiore and $30 \mathrm{~m}$ in Lake Gutiérrez, corresponding to maximum in chlorophyll concentration. Profiles of temperature and Photosynthetic Active Radiation (PAR) were obtained using a PUV 500 (Biosphere) in the Andean lake and a multiparameter probe (IDRONAUT, mod. OS316) in the subalpine lake.

\subsection{Chemical analyses}

Total Phosphorus (TP) was determined after mineralization of the samples with persulfate-boric acid (Valderrama 1981). Soluble Reactive Phosphorus (SRP) was determined according to A.P.H.A. (1992) after sample filtration through $\mathrm{GF} / \mathrm{C}$ (Whatman) filters.

The Dissolved Organic Carbon (DOC) concentration was determined with Shimadzu 5000A TOC Analyser after filtration of the samples through GF/F (Whatman) precombusted glass fibre filters.

\subsection{Bacterial counting and gross taxonomic composition of bacterial assemblages (CARD FISH)}

Total bacteria enumeration was performed by staining with fluorochrome 4',6-diamidino-2-phenylindole
(DAPI; final concentration $2 \% \mathrm{v} / \mathrm{v}$ ) according to Porter $\&$ Feig (1980). Counting was performed on polycarbonate black membrane filters $(0.2 \mu \mathrm{m}$ pore size $)$ at $1250 \times$ magnification.

The gross taxonomic composition of bacterial assemblages was evaluated with the CARD FISH technique performed using horseradish peroxidase-labeled probes and tyramide signal amplification as described by Pernthaler et al. (2002). Water samples of $10 \mathrm{~mL}$ were filtered through $0.2 \mu \mathrm{m}$ Nuclepore polycarbonate filters (47 $\mathrm{mm}$ diameter). Filters were embedded in lowgelling-point agarose, allowed to air dry, and stored at $-20{ }^{\circ} \mathrm{C}$ until further processing. Then, filters were carefully cut and the portions were subjected to cell permeabilization with lysozyme and achromopeptidase according to the protocol by Sekar et al. (2003). The bacterial probes used were EUB338 for Bacteria, ARCH915 for Archaea, ALF1b for the subclass $\alpha$-Proteobacteria, BET42a for the subclass $\beta$-Proteobacteria, GAM42a for the subclass $\gamma$-Proteobacteria, CF319 for the Cytophaga-Flavobacterium group, and HGC69a for the class Actinobacteria. The probe NON338 was used as a control. The filters were counterstained with DAPI (1 mg:100 mL) and inspected with epifluorescence microscope at 1250× magnification (Olympus BX 50 for Lake Gutiérrez and Zeiss Axioplan for Lake Maggiore). At least 20 randomly selected microscopic fields were counted for the enumeration of the FISHstained bacteria and for the total DAPI stained bacteria, and the percent value of each bacterial probe was calculated.

\subsection{Bacterial production}

Bacterial production was measured by ${ }^{14} \mathrm{C}$-leucine according to Smith \& Azam (1992). Samples (1.4 mL in triplicate plus 1 blank for each assay) were added to sterile plastic Eppendorf microcentrifuge tubes $(1.5 \mathrm{~mL})$ followed by addition of $15 \mu \mathrm{L}$ of $90 \mathrm{nM} \mathrm{L}-[\mathrm{U}-$ $\left.{ }^{14} \mathrm{C}\right]$ leucine (specific activity $311 \mathrm{mCi} \mathrm{mmole}^{-1}$, Amersham Life Science Int.). The blank was fixed by addition of $75 \mu \mathrm{L} 100 \%$ trichloroacetic acid (TCA) $15 \mathrm{~min}$ before the addition of radioactive leucine. Tubes were incubated in the dark for $2 \mathrm{~h}$, at the same temperature measured in the lakes, and then to each microcentrifuge tubes $75 \mu \mathrm{L}$ of $100 \%$ TCA was added. Samples were mixed and incubated for $30 \mathrm{~min}$ at $4{ }^{\circ} \mathrm{C}$ and then centrifuged for $10 \mathrm{~min}$ at $12,000 \mathrm{~g}$. The supernatant was carefully removed by aspiration with a disposable syringe; $1.4 \mathrm{~mL}$ of $5 \%$ TCA was then added and, after centrifu- 
gation for $10 \mathrm{~min}$ at $12,000 \mathrm{~g}$, removed by aspiration. The final precipitates were resuspended in $1 \mathrm{~mL}$ of liquid scintillation cocktail (FilterCount, Perkin Elmer) in the same microcentrifuge tubes and the incorporated labeled leucine was quantified by liquid scintillation counter (LS 5000CE Beckman). Leucine incorporation rates were converted into carbon production according to Simon \& Azam (1989). Analytical accuracy of measurements gave a coefficient of variation $(\mathrm{CV})$ of less than $4 \%$.

\subsection{Experimental design}

The laboratory experiments were conducted using lake water from spring and summer samplings (Southern hemisphere: Lake Gutiérrez in November 2005 and January 2006; Northern hemisphere: Lake Maggiore in April and August 2006). The samples were filtered under reduced vacuum through $2 \mu \mathrm{m}$ pore size Nuclepore polycarbonate filter to remove bacterial predators. This pore size was chosen in order to minimize potential biases associated with prefiltration as $1 \mu \mathrm{m}$ pore size filter retained $60 \%$ of the assemblage. We checked by microscope the filtrate to control the presence of micrograzers and we found no flagellates in the filtrate. Inspection of the water at the end of the experiments ( 48 h) showed no presence of flagellates in Lake Gutiérrez and only few in Lake Maggiore (less than 5 cell $\mathrm{mL}^{-1}$ ). Viruses were not inspected; nevertheless we did not observe any mortality of bacteria during the incubation.

Each experiment consisted of an unamended control (U) plus three treatments (all of each in three replicates) enriched with phosphorus $\left(\mathrm{K}_{2} \mathrm{HPO}_{4}\right)(+\mathrm{P})$, labile DOC (glucose) $(+\mathrm{C})$ and, glucose and phosphorus $(+\mathrm{CP})$, in a factorial design. Glucose was selected for the labile DOC enrichment because it is the most abundant dissolved free neutral sugar in aquatic systems, and because it is preferentially utilized relative to other free monosaccharides (Rich et al. 1996). Other sources of labile DOC such as amino acids (AA) were neglected since their application is almost impossible without altering the natural spectrum of AA in a lake. Enrichments of $\mathrm{C}, \mathrm{P}$ or both were added so that final concentrations were double the natural lake concentrations, and so as to maintain the $\mathrm{C}: \mathrm{P}$ ratio in the $+\mathrm{CP}$ treatment as closely as possible to the in situ ratio (Tab. 2).

Tab. 2. C:P ratio (dissolved fraction) at initial $(0 \mathrm{~h})$ time and incubation temperature $\left(\mathrm{Temp}{ }^{\circ} \mathrm{C}\right)$ of the experiments. $\mathrm{U}=$ unamended. $+\mathrm{C},+\mathrm{P},+\mathrm{CP}=$ treatments amended with carbon, phosphorus and both respectively.

\begin{tabular}{lccccc}
\hline & \multicolumn{2}{c}{ L. Maggiore } & & \multicolumn{2}{c}{ L. Gutiérrez } \\
\cline { 2 - 3 } \cline { 5 - 6 } & Spring & Summer & & Spring & Summer \\
\hline Temp & 13 & 21 & & 12 & 16 \\
$\mathrm{U}$ & 155 & 170 & & 336 & 385 \\
$+\mathrm{C}$ & 280 & 337 & & 1421 & 1154 \\
$+\mathrm{P}$ & 69 & 64 & & 78 & 68 \\
$+\mathrm{CP}$ & 124 & 126 & & 331 & 205 \\
\hline
\end{tabular}

All the glassware was acid washed and sterilized before use. Flasks filled with filtered lake water (500 $\mathrm{mL}$ ) were placed into a thermostatic chamber and incubated in the dark, at the lake temperatures (Tab. 2). Samples for DOC and P concentration, bacterial abundance, taxonomic composition and activity were taken at the beginning of incubation (time 0). Samples for bacterial abundance and activity were taken after 4, 24 and 48 hours of incubation. At the end of the experiment $(48 \mathrm{~h})$ the bacterial taxonomic composition was checked again.

\subsection{Statistical Analysis}

Bacterial production data were analyzed through a Two Way RMANOVA and a posteriori multiple comparison test. Bacterial assemblage composition was analyzed with a Two way ANOVA, and an arc sin transformation of the data was applied when needed for fulfil normality and/or homoscedasticity. Finally, a Multiple Comparisons versus Control Group, HolmSidak method, was applied.

\section{RESULTS}

\subsection{Bacterial production and abundance}

The two lakes showed different BP at time 0 in both seasons, being twofold higher in Lake Maggiore (L. Maggiore 0.14 and $0.28 \mu \mathrm{g} \mathrm{C} \mathrm{L}^{-1} \mathrm{~h}^{-1}$ in spring and summer respectively; L. Gutiérrez 0.07 and $0.10 \mu \mathrm{g} \mathrm{C} \mathrm{L}^{-1} \mathrm{~h}^{-1}$ in spring and summer respectively). In Lake Maggiore (Fig. 1, upper panels) both in spring and summer, bacterial production (BP) increased significantly (pairwise multiple comparison, $P<0.05$ ) in the treatments $+\mathrm{CP}$ compared with the unamended samples (U). In summer the BP reached $27.02 \mu \mathrm{g} \mathrm{C} \mathrm{L} \mathrm{L}^{-1} \mathrm{~h}^{-1}$ already after 24 hours, while in spring it was still below $1 \mu \mathrm{g} \mathrm{C} \mathrm{L}^{-1} \mathrm{~h}^{-1}$ after this time.

In Lake Gutiérrez (Fig. 1, lower panels), in the spring experiment, BP increased significantly in the treatments $+\mathrm{P}$ and $+\mathrm{CP}$ (pairwise multiple comparison, $P<0.05$ ). In summer we found a significant increase of BP in all the treatments $(P<0.05)$. In particular in the treatment $+\mathrm{CP}$ we observed differences between spring and summer experiments already after 24-h incubation. The BP of the ultraoligotrophic Lake Gutiérrez was one order of magnitude lower than Lake Maggiore.

The two lakes differed in bacterial abundance, with the ultraoligotrophic Lake Gutiérrez being four- to eleven fold lower than Lake Maggiore, as was visible from the unamended samples at time 0 (Tab. 3). In all the experiments we observed an increase in cell abundance in the $+\mathrm{CP}$ treatment. In Lake Maggiore this increase was higher than in Lake Gutiérrez.

The production per bacterial cell (specific BP) followed a similar trend of BP (data not shown). Specific BP was lower in Lake Maggiore than in Lake Gutiérrez. In Lake Gutiérrez we observed that, in summer, in all 
L. Maggiore, spring

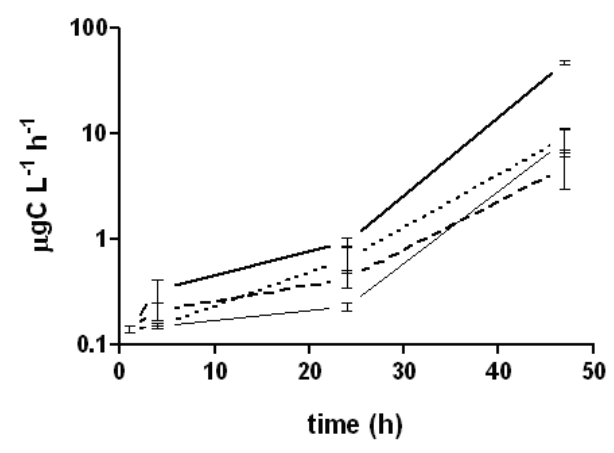

L. Gutiérrez, spring

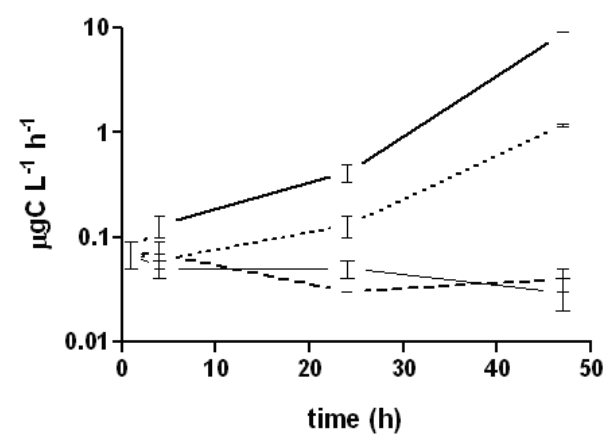

L. Maggiore, summer

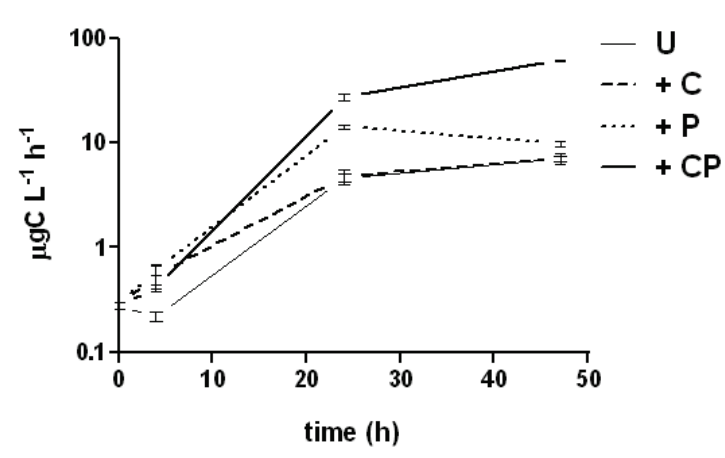

L. Gutiérrez, summer

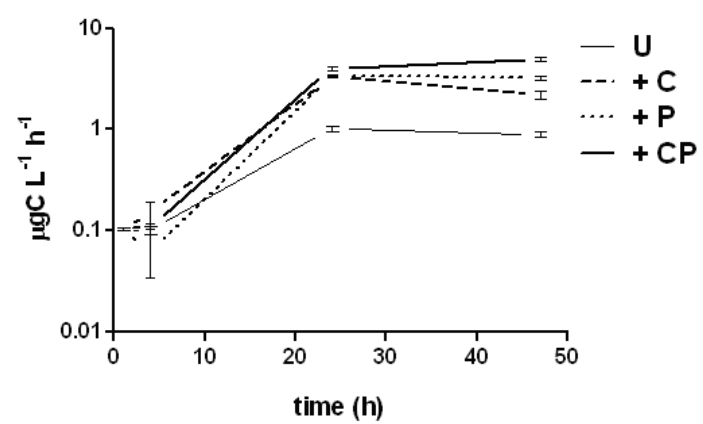

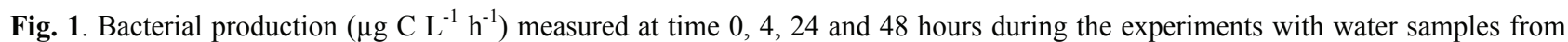
Lake Maggiore and Lake Gutiérrez, in spring and summer. $\mathrm{U}=$ unamended. $+\mathrm{C},+\mathrm{P},+\mathrm{CP}=$ treatments amended with carbon, phosphorus and both respectively. Vertical bars are the standard errors.

Tab. 3. Bacteria abundances $\left(10^{6}\right.$ cells $\left.\mathrm{mL}^{-1}\right)$ at 0 and 48 hours in spring and summer experiments. $\mathrm{U}=$ unamended. $+\mathrm{C},+\mathrm{P},+\mathrm{CP}=$ treatments amended with carbon, phosphorus and both respectively; mean \pm standard error.

\begin{tabular}{l|l|ccccc}
\hline \multicolumn{1}{c}{} & & hours & $\mathrm{U}$ & $+\mathrm{C}$ & $+\mathrm{P}$ & $+\mathrm{CP}$ \\
\hline \multirow{4}{*}{ L. Maggiore } & Spring & 0 & $3.10 \pm 0.17$ & & & \\
& & 48 & $6.27 \pm 0.36$ & $5.93 \pm 0.12$ & $5.23 \pm 0.21$ & $13.68 \pm 1.34$ \\
& Summer & 0 & $6.69 \pm 0.45$ & & & \\
& & 48 & $8.13 \pm 0.33$ & $8.00 \pm 0.30$ & $9.93 \pm 0.02$ & $19.24 \pm 1.24$ \\
\multirow{5}{*}{ L. Gutiérrez } & Spring & 0 & $0.68 \pm 0.04$ & & & \\
& & 48 & $0.64 \pm 0.01$ & $0.81 \pm 0.02$ & $0.82 \pm 0.03$ & $1.05 \pm 0.01$ \\
& Summer & 0 & $0.59 \pm 0.04$ & & & \\
& & 48 & $0.67 \pm 0.05$ & $0.61 \pm 0.03$ & $0.57 \pm 0.02$ & $0.80 \pm 0.02$ \\
\hline
\end{tabular}

the amended treatments the specific BP was close to 5 ng Ce cell ${ }^{-1} \mathrm{~h}^{-1}$ after 24 hours. On the other hand, after 48 hours in the spring experiment, the specific BP reached $8.6 \mathrm{ng} \mathrm{C}$ cell $^{-1} \mathrm{~h}^{-1}$ in the $+\mathrm{CP}$ treatment only. In Lake Maggiore, the specific BP slightly exceeds $3 \mathrm{ng} \mathrm{C}$ cell $^{-1}$ $\mathrm{h}^{-1}$ both in spring and in summer but in this season this value was reached already after 24 hours of incubation.

\subsection{Bacterial assemblage composition}

At the beginning of the experiment $\left(\mathrm{t}_{0}\right)$ in both lakes Bacteria were the dominant fraction detected by CARD-FISH (Lake Maggiore 34 and $53 \%$ of total
DAPI count in spring and summer respectively; Lake Gutiérrez 93 and $81 \%$ of total DAPI count in spring and summer respectively). Archaea were only a minor fraction never exceeding $7 \%$ of total DAPI count at $\mathrm{t}_{0}$. After 48 hours of incubation in all the treatments the Archaea numbers decreased, except in Lake Maggiore in summer where they raised from $0.2 \times 10^{6} \mathrm{cell}^{-1} \mathrm{~mL}^{-1}$ at $\mathrm{t}_{0}$ to $1.6 \times 10^{6}$ cell $^{-1} \mathrm{~mL}^{-1}$ at $\mathrm{t}_{48}$ in $+\mathrm{CP}$ treatment.

At the beginning of the experiment $\left(t_{0}\right)$ the dominant subclass of Bacteria assemblage was $\beta$-Proteobacteria both in Lake Maggiore and Lake Gutiérrez ( $30 \%)$. However, $\gamma$-Proteobacteria differed between the two 


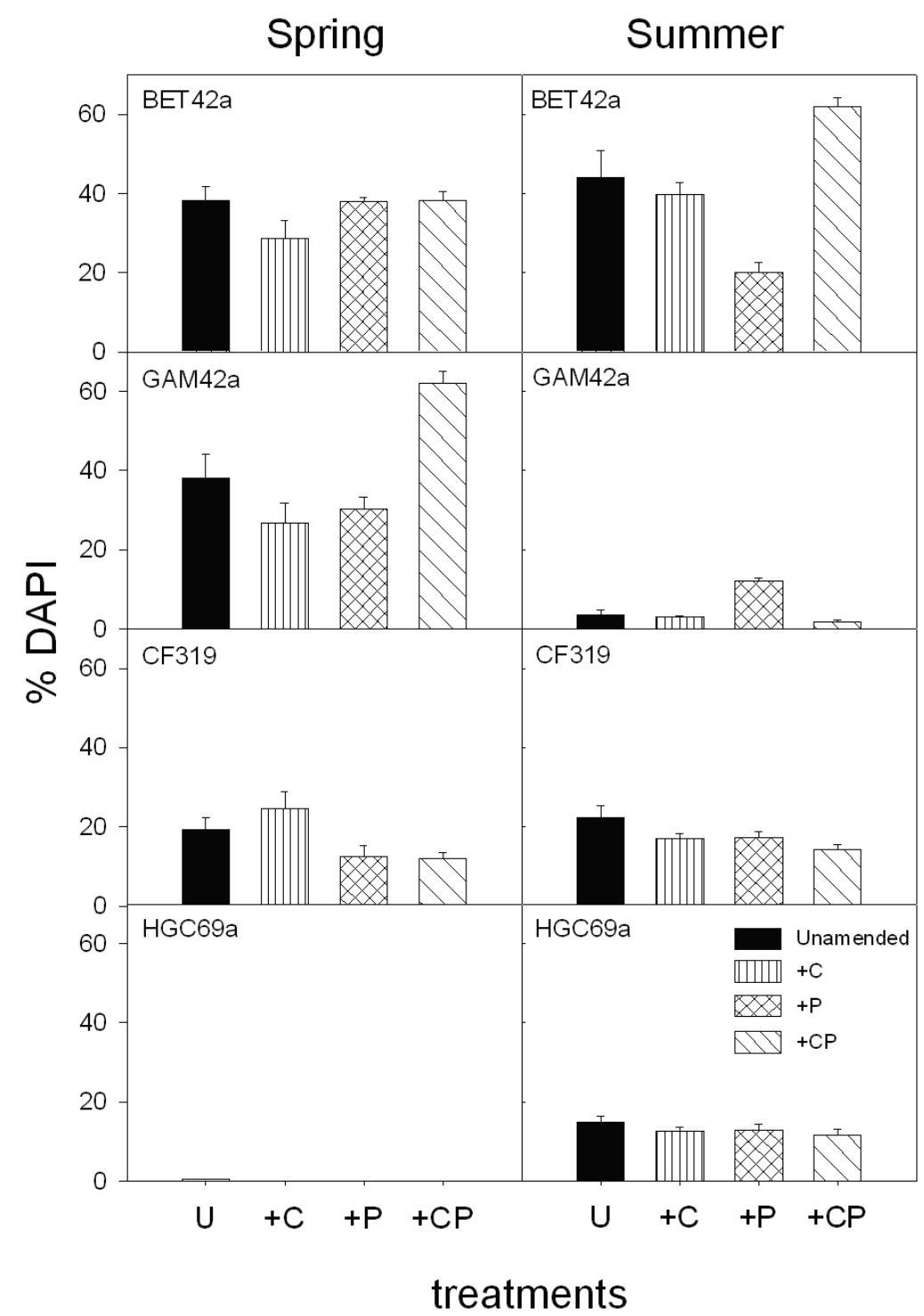

Fig. 2. Percentages of DAPI-stained cells in Lake Maggiore in the treatments $(\mathrm{U}=$ unamended. $+\mathrm{C},+\mathrm{P},+\mathrm{CP}=$ treatments amended with carbon, phosphorus and both respectively), detected by CARD-FISH with oligonucleotide probes (BET42a $=\beta$-Proteobacteria, GAM42a $=\gamma$-Proteobacteria, CF319 = Cytophaga-Flavobacterium, HGC69a = Actinobacteria). Vertical bars are the standard errors.

lakes and seasons, showing an increase of their relative importance in Lake Maggiore in spring $(\sim 20 \%)$ and in Lake Gutiérrez in summer ( 12\%). Cytophaga-Flavobacterium and Actinobacteria exhibited a higher percentage ( $\sim 5 \%$ each) in summer than in spring in both lakes. $\alpha$-Proteobacteria was not present in either lake and therefore was not considered in the statistical analyses and is not shown in the figures.

After 48 hours of incubation the Bacteria dominant groups showed significant changes according to the different seasons and treatments (Fig. 2, Fig. 3, Two Way ANOVA $P<0.05$ in both cases). During spring in Lake Maggiore (Fig. 2) the bacterial composition changed between the treatments due mainly to the increase of $\gamma$ Proteobacteria (post-hoc Holm-Sidak method, $P=$
0.031 ) and to the decrease of Cytophaga-Flavobacterium (post-hoc Holm-Sidak method, $P=0.025$ ). In summer $\beta$-Proteobacteria increased their relative importance mainly in the $+\mathrm{CP}$ treatment (post-hoc HolmSidak method, $P=0.031$ ) whereas $\gamma$-Proteobacteria and Cytophaga-Flavobacterium decreased significantly (post-hoc Holm-Sidak method, $P=0.001$ for $\gamma$-Proteobacteria and $P=0.005$ for Cytophaga-Flavobacterium). Actinobacteria did not exhibit any significant changes either in seasons or in treatments.

In the spring experiments in Lake Gutiérrez (Fig. 3) the bacterial community composition changed due mainly to an increase of $\gamma$-Proteobacteria (post-hoc Holm-Sidak method, $P=0.004$ ) and $\beta$-Proteobacteria (post-hoc Holm-Sidak method, $P=0.043$ ). In summer 


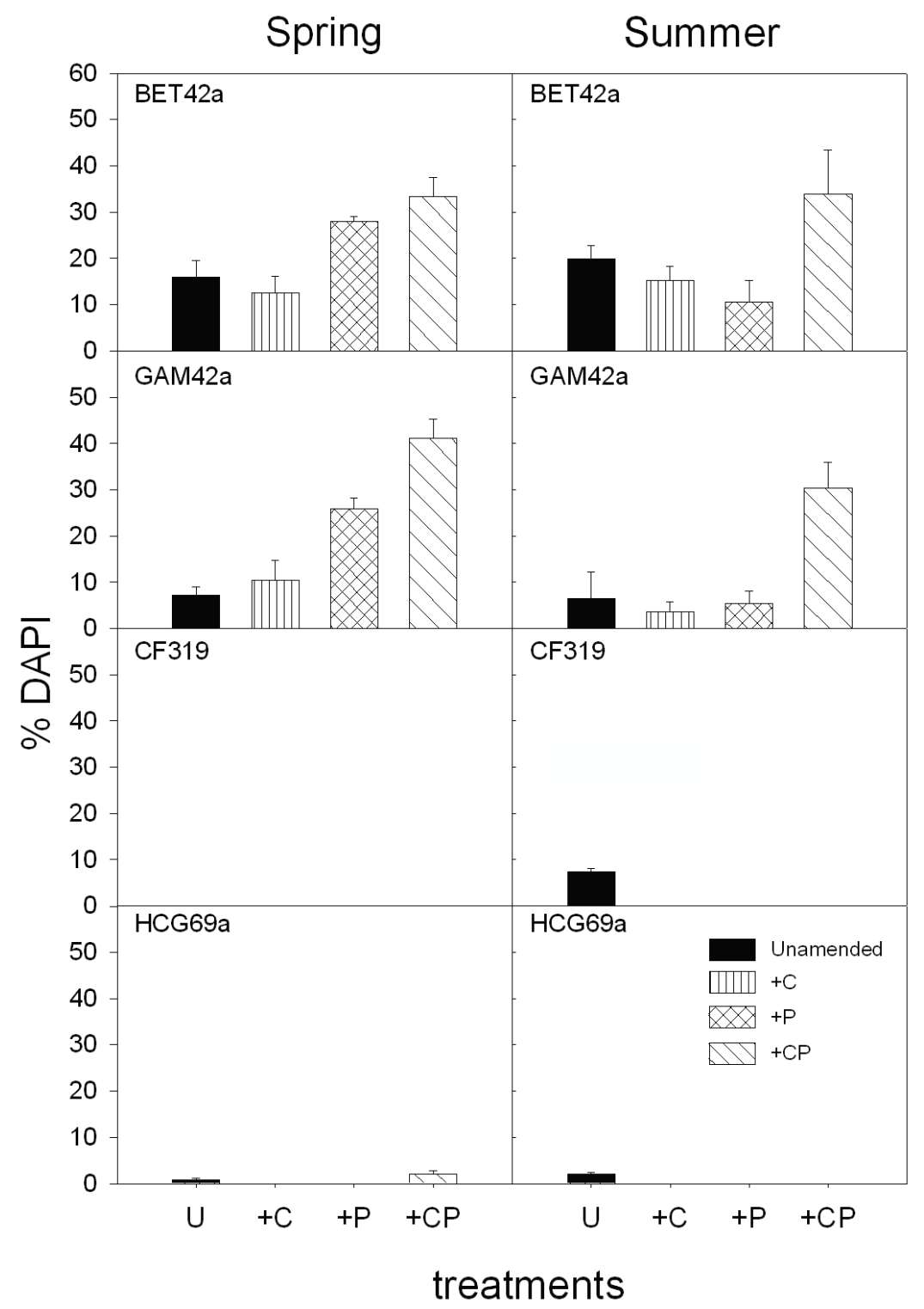

Fig. 3. Percentages of DAPI-stained cells in Lake Gutiérrez in the treatments $(\mathrm{U}=$ unamended. $+\mathrm{C},+\mathrm{P},+\mathrm{CP}=$ treatments amended with carbon, phosphorus and both respectively), detected by CARD-FISH with oligonucleotides probes (BET42a $=\beta$-Proteobacteria, GAM42a $=\gamma$-Proteobacteria, CF319 = Cytophaga-Flavobacterium, HGC69a $=$ Actinobacteria). Vertical bars are the standard errors.

only $\gamma$-Proteobacteria increased significantly in the $+\mathrm{CP}$ treatment (post-hoc Holm-Sidak method, $P=0.010$ ), while $\beta$-Proteobacteria did not exhibit any significant change, and Actinobacteria and Cytophaga-Flavobacterium completely disappeared in all the treatments.

\section{DISCUSSION}

The results of our experiments showed a strong effect of nutrient and carbon additions on bacterial production enhancement in the oligotrophic and ultraoligotrophic lakes. This increase was particularly evident in the $+\mathrm{CP}$ treatment with a quick response in summer (within the first 24 hours of incubation), whereas in the spring the bacterial communities reacted more slowly, showing a production increase only after 48 hours.

As bacterioplankton production in oligotrophic systems is affected by inorganic phosphorous (Vadstein 2000) and organic carbon (Vrede 1996; Caron et al. 2000), we expected a positive response of the bacteria in all the treatments in both lakes. Conversely, we obtained this response only in the ultraoligotrophic non-humic lake, where the availability of carbon and phosphorous is very low.

Eutrophication has been an increasing problem during the last decades, and the load of phosphorus was decisive (Vollenweider 1976). Notwithstanding the recent recovery of Lake Maggiore to its oligotrophic conditions, bacterioplankton activity was not sensitive 
to $+\mathrm{C}$ and $+\mathrm{P}$ treatments indicating that there is an effect of resilience in the oligotrophication process. In this case, the bacterial activity is controlled only in treatments where nutrient and substrate are combined at the original $\mathrm{C}: \mathrm{P}$ ratio of the lake $(\mathrm{C}: \mathrm{P}$ dissolved fraction $<200$ ). On the contrary, the ultraoligotrophic lake appeared to be more sensitive to environmental changes, since an increase in bacterial activity was observed in both the seasons in $+\mathrm{P}$ treatment. These results are in agreement with the indication by Jansson et al. (2006) of a P-limited bacterial production at high DOC:P ratios. Lake Gutiérrez showed in the two seasons higher C:P ratios (C:P dissolved fraction $>300$ ) than Lake Maggiore, therefore, as was observed, solely a P limitation occurred.

In the seasons selected for our experiments there was a difference in the bacterial community composition and in the water temperature. The incubation temperature we used for our experiments was the same as the sampling depth from the lake, therefore we assumed that bacteria were acclimated to this thermal condition. In that sense, Simon \& Wünsch (1998) indicated that in Lake Constance during most of the year the bacteria community was well adapted to temperature regime. Temperature may act on various aspects of an organism's biology, including reproduction, growth rate and nutritional requirements (McArthur 2006). Therefore, the observed dependence of bacterial activity on temperature was expected in our experiments, since it was already documented in a variety of freshwater environments ranging from oligotrophic (Coveney \& Wetzel 1995; Ochs et al. 1995) to mesotrophic and eutrophic states (Simon \& Wünsch 1998; Gurung \& Urabe 1999; Vrede et al. 1999). Besides, Pomeroy \& Wiebe (2001) suggested that substrate concentrations and temperature interact; thus, these factors should be considered simultaneously in evaluating bacterioplankton responses. However, the distinctive bacteria assemblages of both seasons and lakes could also account for the difference in the response time in the different treatments.

The dominant subclass $\beta$-Proteobacteria has opportunistic strategies and grew significantly faster than the bulk bacterioplankton (Burkert et al. 2003; Šimek et al. 2006), reacting very quickly to our experimental $+\mathrm{CP}$ enhancement, in particular in summer in Lake Maggiore. Nevertheless, we were able to observe differences in the relative contribution of the other bacterial groups in both seasons and lakes. After the incubation, in spring, in the $+\mathrm{CP}$ treatment we observed an increase in the relative importance of $\gamma$-Proteobacteria in both lakes. The $\gamma$-Proteobacteria have a preference for high nutrient concentration (Pinhassi \& Berman 2003), because they are typical $r$-strategists able to rapidly exploit the extra nutrients made available (Puddu et al. 2003). Thus, in our experiments they reacted positively in $+\mathrm{P},+\mathrm{CP}$ treatments, particularly in the ultraoligotrophic lake. In summer in Lake Maggiore is likely that the opportunistic strategists $\beta$-Proteobacteria have outcompeted the other groups in the $+\mathrm{CP}$ treatment, thus explaining the low percentage of $\gamma$-Proteobacteria observed.

The Actinobacteria class is also common in a variety of freshwater habitats (Glöckner et al. 2000) and was observed to increase in abundance in the $+\mathrm{CP}$ treatment in spring in Lake Gutiérrez. Cytophaga-Flavobacterium group showed a decrease in all treatments, in particular in the $+\mathrm{CP}$ treatment in summer in Lake Maggiore, where $\beta$-Proteobacteria prevailed. The Cytophaga-Flavobacterium, the largest bacteria group including a great variety of taxa, are involved in the mineralization of complex macromolecules (Glöckner et al. 1999), and this could be the reason for their decrease in the treatments with the addition of dissolved nutrient and readily utilizable carbon.

In conclusion, our results demonstrate the different response of bacterioplankton in lakes at the edges of the oligotrophic range: on one hand, the ultraoligotrophic Lake Gutiérrez and, on the other hand, the oligomesotrophic Lake Maggiore. Therefore we accepted our main hypothesis that the bacterial communities of the two lakes responded differently to nutrient enrichment. In addition, in spite of the low BP, in oligotrophic lakes the response of bacterioplankton to nutrient and substrate increase occurs quickly and results in a significant change in the taxonomic composition of bacterial assemblages.

\section{ACKNOWLEDGEMENTS}

We thank Dr. Andrés Venturino, LIBIQUIMA, Universidad Nacional del Comahue, for laboratory facilities. This work was possible as a result of the International Cooperation Program between CNR (Italy) and CONICET (Argentina). This work was partially supported by FONCyT 01-13395 and CONICET PIP 6507.

\section{REFERENCES}

A.P.H.A. 1992. Standard methods for the examination of water and wastewater. Am. Publ. Health Ass., Washington.

Balseiro, E.G., B. Modenutti, C. Queimaliños \& M. Reissig. 2007. Daphnia distribution in Andean Patagonian lakes: Effect of low food quality and fish predation. Aquat. Ecol., 41: 599-609.

Bertoni, R., R. Piscia \& C. Callieri. 2004. Horizontal heterogeneity of seston, organic carbon and picoplankton in the photic zone of Lago Maggiore, Northern Italy. J. Limnol., 63: 244-249.

Biddanda, B.M., M. Ogdhal \& J. Cotner. 2001. Dominance of bacterial metabolism in oligotrophic relative to eutrophic waters. Limnol. Oceanogr., 46: 730-739.

Burkert, U., K. Warnecke, D. Babenzien, E. Zwirnmann \& J. Pernthaler. 2003. Members of a readily enriched $\beta$-Proteobacterial clade are common in surface waters of a humic lake. Appl. Environ. Microbiol., 69: 6550-6559.

Callieri, C., B. Modenutti, C. Queimaliños, R. Bertoni, \& E. Balseiro. 2007. Production and biomass of picophytoplankton and larger autotrophs in Andean ultraoligotrophic lakes: differences in light harvesting efficiency in deep layers. Aquat. Ecol., 80: 345-362. 
Caron, D.A., E. Lin Lim, R.W. Sanders, M.R. Dennet \& U. Berninger. 2000. Responses of bacterioplankton and phytoplankton to organic carbon and inorganic nutrient additions in contrasting oceanic ecosystems. Aquat. Microb. Ecol., 22: 175-184.

Chrzanowski, T.H., R.W. Sterner \& J.J. Elser. 1995. Nutrient enrichment and nutrient regeneration stimulate bacterioplankton growth. Microb. Ecol., 29: 221-230.

Cotner, J. \& B.A. Biddanda. 2002. Small players, large role: Microbial influence on biogeochemical processes in pelagic aquatic ecosystems. Ecosystems, 5: 105-121.

Coveney, M.F. \& R.G. Wetzel. 1992. Effects of nutrients on specific growth rate of bacterioplankton in oligotrophic water cultures. Appl. Environ. Microbiol., 58: 150-156.

Coveney, M.F. \& R.G. Wetzel. 1995. Biomass, production, and specific growth rate of bacterioplankton and coupling to phytoplankton in an oligotrophic lake. Limnol. Oceanogr., 40: 1187-1200.

Eiler, A., S. Langenheder, S. Bertilsson \& L.J. Tranvik. 2003. Heterotrophic bacterial growth efficiency and community structure at different natural organic carbon concentrations. Appl. Environ. Microbiol., 69: 3701-3709.

Felip, M., M.L. Pace \& J.J. Cole. 1996. Regulation of planktonic bacterial growth rates: the effects of temperature and resources. Microb. Ecol., 31: 15-28.

Glöckner, F.O., E. Zaichikov, N. Belkova, L. Dessinova, J. Pernthaler, A. Pernthaler \& R. Amann. 2000. Comparative $16 \mathrm{~S}$ rRNA analysis of lake bacterioplankton reveals globally distributed phylogenetic clusters including an abundant group of Actinobacteria. Appl. Environ. Microbiol., 66: 5053-5065.

Glöckner, F.O., B.M. Fuchs \& R. Amann. 1999. Bacterioplankton compositions of lakes and oceans: a first comparison based on fluorescence in situ hybridization. Appl. Environ. Microbial., 65: 3721-3726.

Graneli, W., S. Bertilsson \& A. Philibert. 2004. Phosphorus limitation of bacterial growth in high Arctic lakes and ponds. Aquat. Sci., 66: 430-439.

Gurung, T.B. \& J. Urabe. 1999. Temporal and vertical difference in factors limiting growth rate of heterotrophic bacteria in Lake Biwa. Microb. Ecol., 38: 136-145.

Jansson, M., A. Bergström, D. Lymer, K. Vrede \& J. Karlsson. 2006. Bacterioplankton growth and nutrient use efficiencies under variable organic carbon and inorganic phosphorus ratios. Microb. Ecol., 52: 358-364.

Mc-Arthur, J.V. 2006. Microbial Ecology: an evolutionary approach. Elsevier. Burlington USA: $416 \mathrm{pp}$.

Ochs, C. A., J.J. Cole \& G.E. Likens. 1995. Population dynamics of bacterioplankton in an oligotrophic lake. $J$. Plankton Res., 17: 365-391.

Pernthaler, A, J. Pernthaler \& R. Amann. 2002. Fluorescence in situ hybridization and Catalyzed Reporter Deposition for the identification of marine bacteria. Appl. Environ. Microbiol., 68: 3094-3101.

Pinhassi, J. \& T. Berman. 2003. Differential growth response of colony-forming $\alpha$ and $\gamma$-Proteobacteria in dilution culture and nutrient addition experiments from Lake Kinneret (Israel), the Eastern Mediterranean Sea, and the Gulf of Eilat. Appl. Environ. Microbiol., 69: 199-211.

Pomeroy, L.R. \& W.J. Wiebe. 2001. Temperature and substrates as interactive limiting factors for marine heterotrophic bacteria. Aquat. Microb. Ecol., 23: 187-204.

Porter, K.G. \& Y.S. Feig. 1980. The use of DAPI for identifying and counting aquatic microflora. Limnol. Oceanogr., 25: 943-948.

Received: June 2008

Accepted: August 2008
Puddu, A., A. Zoppini, S. Fazi, M. Rosati, S. Amalfitano \& E. Magaletti. 2003. Bacterial uptake of DOM released from P-limited phytoplankton. FEMS Microb. Ecol., 46: 257268.

Rich, J. H., H.W. Ducklow \& D.L. Kirchman. 1996. Concentrations and uptake of neutral monosaccharides along 140 degrees $\mathrm{W}$ in the equatorial Pacific: Contribution of glucose to heterotrophic bacterial activity and the DOM flux. Limnol. Oceanogr., 41: 595-604.

Salmaso, N., G. Morabito, L. Garibaldi \& R. Mosello. 2007. Trophic development of the deep lakes south of the Alps: a comparative analysis. Fundamental and Applied Limnology, 170: 177-196.

Sekar, R., A. Pernthaler, J. Pernthaler, F. Warnecke, T. Posch \& R. Amann. 2003. An improved protocol for quantification of freshwater Actinobacteria by Fluorescence In Situ Hybridization. Appl. Environ. Microbiol., 69: 2928-2935.

Schweitzer, B. \& M. Simon. 1995. Growth limitation of planktonic bacteria in a large mesotrophic lake. Microbial Ecology, 30: 89-104.

Šimek, K., K. Hornak, J. Jezbera, J. Nedoma, J. Vrba, V. Straskrabova, M. Macek, J.R. Dolan \& M. W. Hahn. 2006. Maximum growth rates and possible life strategies of different bacterioplankton groups in relation to phosphorus availability in a freshwater reservoir. Environ. Microbiol., 8: 1613-1624.

Simon, M. \& K. Azam. 1989. Protein content and protein synthesis rates of planktonic marine bacteria. Mar. Ecol. Prog. Ser., 51: 201-213.

Simon, M. \& C. Wünsch. 1998. Temperature control of bacterioplankton growth in an temperate large lake. Aquat. Microb. Ecol., 16: 119-130.

Smith, D.C. \& K. Azam. 1992. A simple, economical method for measuring bacterial protein synthesis rates in seawater using 3H-leucine. Mar. Microb. Food Webs, 6: 107-114.

Toolan, T., J.D. Wehr \& S. Findlay. 1991. Inorganic phosphorus stimulation of bacterioplankton productionin a mesoeutrophic lake. Appl. Environ. Microbiol., 57: 2074-2078.

Vadstein, O. 2000. Heterotrophic, planktonic bacteria and cycling of phosphorus. Phosphorus requirements, competitive ability and food web interaction. Adv. Microb. Ecol., 16: 115-167.

Valderrama, J.C. 1981. The simultaneous analysis of total nitrogen and total phosphorus in natural water. Mar. Chem., 10: $102-122$

Van Hannen, E.J., W. Mooij, M.P. Van Agterveld, H.J. Gons \& H.J. Laanbroek. 1999. Detritus-dependent development of the microbial community in an experimental system: qualitative analysis by Denaturing Gradient Gel Electrophoresis. Appl. Environ. Microbiol., 65: 2478-2484.

Vollenweider, R.A. 1976. Advances in defining critical loading levels for phosphorus in a eutrophic lake. Mem. Ist. ital. Idrobiol., 33: 53-83.

Vrede, K. 1996. Regulation of bacterioplankton production and biomass in an oligotrophic clearwater lake - the importance of the phytoplankton community. J. Plankton Res., 18: 1009-1032.

Vrede, K. 2005. Nutrient and temperature limitation of bacterioplankton growth in temperate lakes. Microb. Ecol., 49: 245-256.

Vrede, K., T. Vrede, A. Isaksson \& A. Karlsson. 1999. Effects of nutrients $(\mathrm{P}, \mathrm{N}, \mathrm{C})$ and zooplankton on bacterioplankton and phytoplankton - a seasonal study. Limnol. Oceanogr., 44: 1616-1624. 